\title{
Effects of the cyclophilin-type peptidylprolyl cis-trans isomerase from Pyropia yezoensis against hydrogen peroxide-induced oxidative stress in HepG2 cells
}

\author{
EUN-YOUNG KIM ${ }^{1}$, YOUN HEE $\mathrm{CHOI}^{1}, \mathrm{CHANG}$ GEUN CHOI ${ }^{2}$ and TAEK-JEONG NAM ${ }^{1}$ \\ ${ }^{1}$ Institute of Fisheries Sciences, Pukyong National University, Ilgwang-myeon, Gijang-gun, Busan 46041; \\ ${ }^{2}$ Department of Ecological Engineering, Pukyong National University, Nam-Gu, Busan 48513, Republic of Korea
}

Received June 8, 2016; Accepted March 2, 2017

DOI: $10.3892 / \mathrm{mmr} .2017 .6517$

\begin{abstract}
The present study aimed to describe the expression and purification of cyclophilin-type peptidylprolyl cis-trans isomerase (PPI) from the red alga Pyropia yezoensis. The antioxidant activity of the purified protein was also demonstrated, based on its ability to act against oxidative stress in HepG2 human hepatocellular carcinoma cells. HepG2 cells that were treated with recombinant PPI protein exhibited a reduction in the formation of hydrogen peroxide $\left(\mathrm{H}_{2} \mathrm{O}_{2}\right)$-mediated reactive oxygen species (ROS). In HepG2 cells, treatment of recombinant PPI protein expression diminished $\mathrm{H}_{2} \mathrm{O}_{2}$-mediated oxidative stress and restored both the expression and the activity of certain antioxidant enzymes, including superoxide dismutase (SOD), catalase (CAT), glutathione peroxidase (GPx) and thioredoxin reductase (TRR). CAT, SOD and TRR activities were upregulated by treatment with the purified protein. CAT mRNA expression was significantly increased in HepG2 cells treated with recombinant PPI protein. These enzymes are the first line of antioxidant defense against ROS generated in times of oxidative stress. Accordingly, data from the present study indicate that the recombinant PPI protein is able to regulate the expression of antioxidant enzymes. Recombinant PPI has antioxidant properties that prevent oxidative stress-induced toxicity, enhance cell viability, decrease ROS production and inhibit oxidative damage and mitochondrial dysfunction in HepG2 cells. Therefore, the present study hypothesizes that the recombinant PPI protein has the potential to protect the liver against oxidative stress-induced cell damage and should be considered as an antioxidant.
\end{abstract}

Correspondence to: Professor Taek-Jeong Nam, Institute of Fisheries Sciences, Pukyong National University, 474 Ilgwang-ro, Ilgwang-myeon, Gijang-gun, Busan 46041, Republic of Korea E-mail:namtj@pknu.ac.kr

Key words: Pyropia yezoensis, cyclophilin-type peptidylprolyl cis-trans isomerase, antioxidant activity, reactive oxygen species

\section{Introduction}

Reactive oxygen species (ROS) that are generated in vivo are a major cause of human aging and disease (1). ROS expression leads to disease through toxic effects on cells and tissues. ROS include free radical species, such as superoxide anion $\left(\mathrm{O}_{2}^{-}\right)$, hydroxyl radical and singlet oxygen, as well as non-radical species such as hydrogen peroxide $\left(\mathrm{H}_{2} \mathrm{O}_{2}\right)$. ROS are neutralized by antioxidant enzymes, including superoxide dismutase (SOD), catalase (CAT), glutathione peroxidase (GPx) and glutathione reductase, or by small molecules, such as ascorbic acid, $\alpha$-tocopherol and glutathione (GSH), during normal physiological metabolic processes. Oxidizing agents and oxidation inhibitors function to maintain reduction-oxidation (redox) homeostasis in the body. However, perturbations in this balance, either caused by excess production of ROS or decreased or malfunctioning antioxidant defenses, may result in oxidative stress, potentially leading to pathological effects (1-4). ROS may be detrimental to cells by inducing oxidative damage to lipids, proteins and DNA (5). Therefore, it is important to balance ROS levels with endogenous antioxidant enzymes and, when required, antioxidant compounds.

Oxidative stress has been associated with a number of diseases, including inflammatory diseases, acquired immunodeficiency syndrome, gastric ulcers, hypertension, neurological disorder, alcoholism and smoking-related diseases (4). Over $90 \%$ of ROS are produced in the mitochondria during cellular respiration. During this process, most oxygen is converted into water $\left(\mathrm{H}_{2} \mathrm{O}\right)$, and a one-electron reduction of molecular oxygen $\left(\mathrm{O}_{2}\right)$ produces $\mathrm{O}_{2}{ }^{-}$, a primary $\mathrm{ROS}$, which is subsequently transformed into hydrogen peroxide $\left(\mathrm{H}_{2} \mathrm{O}_{2}\right)$ by SOD. $\mathrm{H}_{2} \mathrm{O}_{2}$ is an oxygen metabolite of central importance that is produced in the mitochondria, as well as in other sites in the cell. $\mathrm{H}_{2} \mathrm{O}_{2}$ itself has weak biological reactivity; however, if present at a cellular concentration of at least $10 \mu \mathrm{M}$, it can directly damage cellular components, including inactivating enzymes by oxidizing active site thiol groups $(2,3)$.

ROS levels are tightly controlled in the body by antioxidant enzymes, including SOD, CAT, GPx and thiol-containing small molecules such as GSH. SODs catalyze the dismutation of $\mathrm{O}_{2}{ }^{-}$to $\mathrm{H}_{2} \mathrm{O}_{2}$ and $\mathrm{O}_{2}$, and are located in the cytoplasm [copper $(\mathrm{Cu})$ - and zinc $(\mathrm{Zn})$-dependent SOD] and in the mitochondria 
[manganese-dependent (Mn)-SOD] (6). CAT is a tetrameric iron-porphyrin protein in peroxisomes that converts $\mathrm{H}_{2} \mathrm{O}_{2}$ to $\mathrm{H}_{2} \mathrm{O}$ and $\mathrm{O}_{2}(7)$. CAT and $\mathrm{Cu} / \mathrm{Zn}-\mathrm{SOD}$ are expressed constitutively, whereas Mn-SOD expression within the mitochondria is induced by oxidative stress. GSH is a sulfhydryl peptide that may directly react with $\mathrm{O}_{2}^{-}$or $\mathrm{N}_{2}$-containing free radicals, or is able to donate electrons in the enzymatic dismutation of $\mathrm{H}_{2} \mathrm{O}_{2}$ to $\mathrm{H}_{2} \mathrm{O}$ and $\mathrm{O}_{2}$ by GPx (8).

ROS removal involves the cooperation of 29 associated genes and 15 corresponding gene expression products (3). The regulation of intracellular antioxidant activity is regulated by a complex network of these genes. The expression of antioxidant enzymes is altered by oxidative stress. The antioxidant defense system within cells includes $\sim 50$ antioxidant-related genes that are divided into four categories (3-9): i) CAT/SOD family members, which include the classic antioxidant enzymes CAT and SODs; ii) proteins involved in GSH metabolism, including GPx, glutaredoxins, glutathione reductase and glucose-6-phosphate dehydrogenase, which promote the antioxidant activity of thiol-containing small molecules, such as GSH, and GSH recycling; iii) proteins involved in redox balance, including enzymes of thioredoxin (TRX) metabolism, TRX, TRX reductase (TRR) and peroxiredoxin (PRDX); and iv) pentose phosphate cycle proteins, including glucose 6-phosphate dehydrogenase. The present study investigated the antioxidant effects of a purified protein on the mRNA expression the antioxidant enzymes SOD, CAT, GPx, and TRR.

Cyclophilin (Cyp) is a multifunctional protein family, which includes cyclophilin-type peptidylprolyl cis-trans isomerase (PPI), a protein which may be inhibited by cyclosporin A (CsA) (10). CsA generates ROS and lipid peroxidation in cells, which appears to be directly associated with its pathological effects. Perez et al (11) used 2',7'-dichlorofluorescein diacetate (DCF-DA) and demonstrated that 1-10 $\mu \mathrm{M}$ CsA generated an oxidized DCF signal, interpreted as being $\mathrm{H}_{2} \mathrm{O}_{2}$-derived. CsA was demonstrated to increase lipid peroxidation in the rat kidney and liver in vivo $(12,13)$. Cyp is a ubiquitous protein that is present in all subcellular compartments, and therefore may potentially be involved in a variety of processes, including protein trafficking and maturation, receptor complex stabilization, apoptosis, receptor signaling, RNA processing and spliceosome assembly (14-20). It has been proposed that CsA-induced oxidative stress may activate or deactivate transcription factors and thus affect gene transcription. Similarly, ROS generated by CsA may activate or deactivate various signaling molecules and influence their downstream transduction systems. The ROS induced by CsA has been reported to affect mitogen-activated protein kinase and transforming growth factor- $\beta$ signaling (21). In particular, there is increased expression of TRX 1 via the ERK/MAPK-2 signaling, to overcome the oxidative stress resulting from ROS. In the present study, PPI, known to exhibit antioxidant activity, was cloned from Pyropia yezoensis. In addition, hydrogen peroxide was used to experimentally induce oxidative stress that results from CsA.

In the sea, the exposure of seaweeds to sunlight and oxygen leads to formation of ROS; however, no oxidative damage is evident in their structural and functional components, which suggests that they may have an efficient antioxidant defense system. Hence, several seaweed extracts are attracting scientific interest to identify new and effective antioxidant compounds (22-27). A recent report described antioxidant agents isolated from seaweed (22). Ismail and Tan (23) compared the antioxidant capacity of commercial seaweeds and confirmed high antioxidant activities of Porphyra sp., Laminaria sp., Undaria sp. and Hijikia sp. Other studies have described high antioxidative properties of many compounds isolated from seaweed, including phlorotannin, fucoxanthin, carotenoids and tocopherols (24-27). Previous studies on the antioxidant properties of algae focused primarily on crude extracts (28-30). In the present study, the gene expression and purification of the antioxidant protein PPI from $P$. yezoensis is described. In addition, the antioxidant activity of recombinant PPI, that is, its protection against ROS, was investigated in a human hepatocellular carcinoma cell line.

\section{Materials and methods}

Seaweeds and cDNA synthesis. P. yezoensis was collected directly from Myeongji (Busan, Korea) and stored at $-70^{\circ} \mathrm{C}$. Frozen samples were lyophilized using a freezing dryer $\left(-80^{\circ} \mathrm{C}\right.$, $24 \mathrm{~h}$ ) and homogenized using a blender into powder, prior to mRNA extraction. mRNA $(5 \mu \mathrm{g})$ was extracted from $20 \mathrm{mg}$ $P$. yezoensis with the GeneJET Plant RNA Purification Mini kit (Thermo Scientific, Inc., Waltham, MA, USA), according to the manufacturer's protocol. Quantification of RNA was performed using the NanoDrop 2000 Spectrophotometer (Thermo Fisher Scientific, Inc., Waltham, MA, USA). The ratio of absorbance at $260 \mathrm{~nm}$ and $280 \mathrm{~nm}$ was used to assess the purity of RNA. A ratio of $<2.0$ was accepted as pure for RNA. The mRNA was used for first strand cDNA synthesis and double strand cDNA synthesis using a PrimeScript Double strand cDNA synthesis kit (Takara Bio, Inc., Otsu, Japan) following the manufacturer's protocol.

Preparation and identification of recombinant PPI protein. To prepare PPI, a forward primer (5'-GGCCCATATGGGGAA CCCGCAGGTGTTCT-3') containing the Nde1 site (underlined) and initiation codon (italic) and reverse primer (5'-GGC CCTCGAGGAGCTCGCCGCAGTCCGC-3') containing Xhol site (underlined), were constructed. Polymerase chain reaction (PCR) amplification was performed using the cDNA of $P$. yezoensis (one cycle at $95^{\circ} \mathrm{C}$ for $5 \mathrm{~min} ; 30$ cycles at $95^{\circ} \mathrm{C}$ for $30 \mathrm{sec}, 55^{\circ} \mathrm{C}$ for $30 \mathrm{sec}$, and $72^{\circ} \mathrm{C}$ for $30 \mathrm{sec}$; followed by one cycle of $72^{\circ} \mathrm{C}$ for $7 \mathrm{~min}$ ) using EXTaq DNA polymerase (Takara Bio Inc., Otsu, Japan). The PCR products (151 bp) and expression vector $\mathrm{pET} 22 \mathrm{~b}^{+}$were digested with two restriction enzymes (NdeI and XhoI). The PCR fragment was subcloned into the digested $\mathrm{pET} 22 \mathrm{~b}^{+}$vector with a DNA ligation kit (Takara Bio Inc.). The resulting plasmid was named pETppi. The pETppi was introduced into Escherichia coli DH5 $\alpha$ competent cells, used as the cloning host for propagation of the expression vector, and finally retransformed into expression strain E. coli BL21 (DE3), according to a previously described method (31). The transformation bacteria were selected on LB agar medium containing $100 \mu \mathrm{g}-\mathrm{ml}^{-1}$ of ampicillin. Cultures of the transformed $E$. coli BL21 overexpressed a recombinant PPI of the expected molecular mass $(\sim 18 \mathrm{kDa})$, which was purified by affinity chromatography in Ni-NTA purification system (Thermo Fisher Scientific, Inc.) according to the manufacturer's protocol. Bacterial cultures were incubated using 
$\mathrm{LB}$ medium at $37^{\circ} \mathrm{C}$ until reaching the OD600 of 0.8 . For PPI expression, isopropyl-beta-D-thiogalactopyranoside (IPTG) was added to a final concentration of $1 \mathrm{mM}$. Expression was continued for $4 \mathrm{~h}$. EnterokinaseMax ${ }^{\mathrm{TM}}$ enzyme (Thermo Fisher Scientific, Inc.) was used to separate the 6x His-tag from recombinant PPI protein, according to the manufacturer's protocol. Analysis of protein expression and purification were carried out using sodium dodecyl sulfate -poly acrylamide gel electrophoresis (SDS-PAGE). The purified recombinant PPI protein was confirmed using SDS-PAGE and electrospray ionization quadrupole time-of-flight mass spectrometry/mass spectrometry (ESI-Q-TOF MS/MS), according to a previously described method (32). The proteins were identified via an NCBI search using the MASCOT program (http://www. matrixscience.com, Matrixscience, London, UK).

Cell culture and viability. HepG2 human hepatocellular carcinoma cells were obtained from the American Type Culture Collection (ATCC, Manassas, VA, USA). Cells were cultured at $37^{\circ} \mathrm{C}$ in a humidified $5 \% \mathrm{CO}_{2}, 95 \%$ air equilibrated incubator in minimum essential medium (MEM) supplemented with heat-inactivated $10 \%$ fetal bovine serum (HyClone, Logan, UT, USA), penicillin (100 U- $\left.\mathrm{ml}^{-1}\right)$ and streptomycin $\left(100 \mu \mathrm{g}-\mathrm{ml}^{-1}\right)$. Adherent cells at $70-80 \%$ confluence were detached by trypsin-EDTA solution and re-plated.

Cell viability was estimated with the CytoX Cell Viability Assay kit (LPS Solution, Daejeon, Korea). Briefly, cells $\left(1.0 \times 10^{3}\right.$ cells/well) were seeded in a 96 -well plate. Various concentrations $\left(0.001,0.01,0.1\right.$ and $\left.1 \mu \mathrm{g}-\mathrm{ml}^{-1}\right)$ of recombinant PPI protein were added to the cells along with $1 \mathrm{mM}$ $\mathrm{H}_{2} \mathrm{O}_{2}$ for $1 \mathrm{~h}$ at $37^{\circ} \mathrm{C}$. Following incubation, Cyto solution was added to each well and incubated for an additional $1 \mathrm{~h}$ at $37^{\circ} \mathrm{C}$. Absorbance was measured with a microplate reader (BioTek Instruments, Inc., Winooski, VT, USA) at a wavelength of $450 \mathrm{~nm}$. The viability of purified recombinant PPI protein-treated cells was expressed as a percentage of that in negative control cells (-, without $\mathrm{H}_{2} \mathrm{O}_{2}$ ).

Assessment of ROS production. The effects of purified recombinant PPI protein on ROS production was evaluated using the cell-permeable probe DCF-DA. DCF-DA (Sigma-Aldrich; Merck KGaA, Darmstadt, Germany) was dissolved in $10 \mathrm{mg}-\mathrm{ml}^{-1}$ sterile dimethylsulfoxide and was used at a concentration of $50 \mu \mathrm{g}-\mathrm{ml}^{-1}$. HepG2 cells were seeded onto 96 -well plates at $1.0 \times 10^{3}$ cells/well in MEM, grown until confluence, and pre-incubated with DCF-DA for $20 \mathrm{~min}$ at $37^{\circ} \mathrm{C}$ in the dark. After washing twice with phosphate buffered saline (PBS) to remove the unattached probe, cells were treated with PBS or various concentrations (between 0.001 and $1 \mu \mathrm{g}-\mathrm{ml}^{-1}$ ) of purified recombinant PPI protein in the presence or absence of $1 \mathrm{mM} \mathrm{H}_{2} \mathrm{O}_{2}$ for $1 \mathrm{~h}$. Fluorescence was measured at 485/20 nm excitation and 535/20 nm emission using a FilterMax F5 Multi-Mode Microplate Reader (Molecular Devices, LLC, Sunnyvale, CA, USA).

Assessment of antioxidant enzyme activities. HepG2 cells were grown to $70-80 \%$ confluence at $37^{\circ} \mathrm{C}$. Following $4 \mathrm{~h}$ starvation, the cells were treated with PBS or various concentrations (0.001-1 $\left.\mu \mathrm{g}-\mathrm{ml}^{-1}\right)$ of purified recombinant PPI protein in the presence or absence of $1 \mathrm{mM} \mathrm{H}_{2} \mathrm{O}_{2}$ for $1 \mathrm{~h}$ and harvested in lysis buffer containing $50 \mathrm{mM}$ Tris- $\mathrm{HCl}(\mathrm{pH} 7.5), 150 \mathrm{mM}$ sodium chloride, $0.5 \%$ sodium deoxycholate, $0.1 \%$ SDS, $1 \%$ triton X-100 and $2 \mathrm{mM}$ ethylenediaminetetra-acetic acid with inhibitors (1 mM sodium orthovanadate and $1 \mathrm{mM}$ phenylmethylsulfonyl fluoride). Cell debris was removed by centrifugation at $13,000 \mathrm{x} \mathrm{g}$ at $4^{\circ} \mathrm{C}$ for $10 \mathrm{~min}$ and the supernatant was used for further measurements. Protein concentration was determined using the BCA Protein assay (Pierce; Thermo Fisher Scientific, Inc., Waltham, MA, USA), according to the manufacturer's protocol. Each supernatant contained an equal amount of protein $(5 \mu \mathrm{g})$ and was used for the subsequent enzyme activity assays. The activities of antioxidant enzymes, including CAT, SOD, GPx and TRR were measured using a Catalase Assay kit (Sigma-Aldrich; Merck KGaA, Darmstadt, Germany), SOD Assay Kit-WST (Sigma-Aldrich; Merck KGaA), Glutathione Peroxidase Cellular Activity Assay kit (Sigma-Aldrich; Merck $\mathrm{KGaA}$ ) and Thioredoxin Reductase Assay kit (Sigma-Aldrich; Merck KGaA) according to the manufacturer's protocols. The absorbance was measured using a microplate reader (BioTek Instruments, Inc., Winooski, VT, USA).

Reverse transcription (RT)-PCR. The effects of recombinant PPI on antioxidant enzyme mRNA expression in $\mathrm{H}_{2} \mathrm{O}_{2}$ treated HepG2 cells was evaluated by RT-PCR. Total RNA was extracted from HepG2 cells using TRIzol Reagent (Invitrogen; Thermo Fisher Scientific, Inc.) according to the manufacturer's protocols. Quantification of RNA was performed as described above. The purity of the RNA was determined at absorbance ratios of 260 and $280 \mathrm{~nm}(260 / 280 \mathrm{~nm}<2.0)$. cDNA was synthesized using a First-Strand cDNA Synthesis kit (Thermo Fisher Scientific, Inc.) according to the manufacturer's protocol. In this experiment, primer sets of SOD2, GPx and CAT were used as reported in Schmidt et al (33) and primer sets of GAPDH and TRR were designed as described by Aguilar-Melero et al (34). PCR amplification was performed using the template cDNA (1 ng) and PCR Amplification Kit (Takara Bio Inc.) Initial denaturation at $95^{\circ} \mathrm{C}$ for $5 \mathrm{~min}$, followed by 25 cycles of $95^{\circ} \mathrm{C}$ for $30 \mathrm{sec}, 55^{\circ} \mathrm{C}$ for $30 \mathrm{sec}$ and $72^{\circ} \mathrm{C}$ for $30 \mathrm{sec}$, then a final extension of $72^{\circ} \mathrm{C}$ for $5 \mathrm{~min}$. Amplified products were analyzed by $1 \%$ agarose gel electrophoresis and stained with ethidium bromide for detection. The software GeneTools, version 4.03 (SYNGENE, Cambridge, UK) was used for densitometry.

Statistical analysis. Data are expressed as the mean \pm standard deviation and were evaluated by one-way analysis of variance using the statistical package for social sciences version 10.0 (SPSS, Ins., Chicago, IL, USA). Values were compared with controls using analysis of variance followed by Duncan's multiple range test. $\mathrm{P}<0.05$ was considered to represent a statistically significant difference.

\section{Results}

Expression and purification of recombinant PPI protein. The expression vector pETppi of P. yezoensis was transformed into E. coli BL21 (DE3) and then induced by $1 \mathrm{mM}$ IPTG. SDS-PAGE analysis of the harvested cells from the pETppi transformed E. coli (BL21) exhibited high amounts of a polypeptide with the expected molecular mass of $\sim 18 \mathrm{kDa}$ (Fig. 1A, lane 2) from SDS-PAGE analysis. Recombinant PPI was 
A

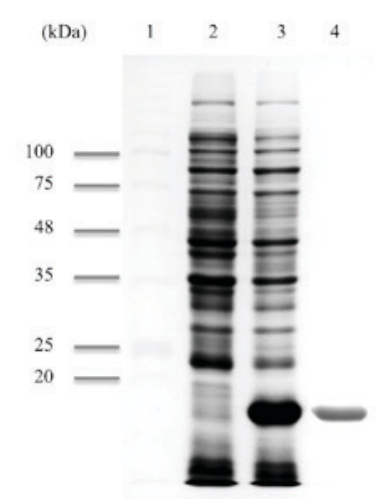

B

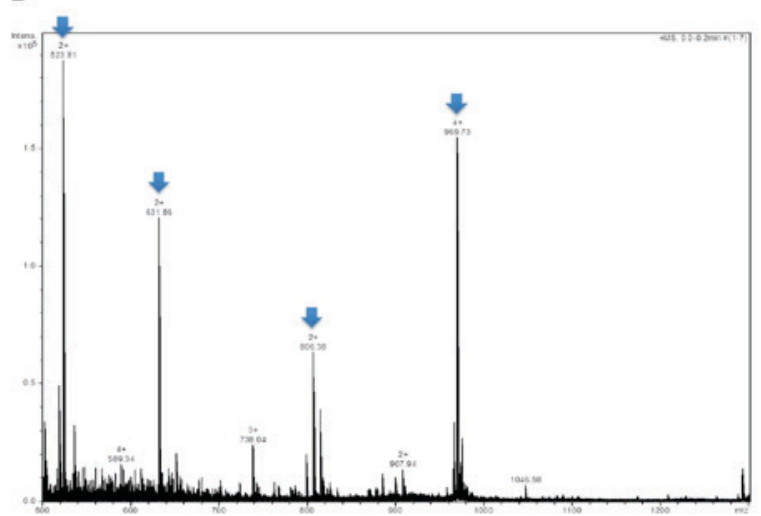

Figure 1. Purification and identification of recombinant PPI protein. (A) SDS-PAGE analysis of PETppi transformed E.coli BL21 (DE3) and purified recombinant PPI. Lane 1, protein marker; lane 2, crude extract of pETppi transformed E. coli BL21 (DE3) prior to induction; lane 3, crude extract of pETppi transformed E. coli BL21 (DE3) after induction with $1 \mathrm{mM}$ IPTG for $4 \mathrm{~h}$; lane 4, purified recombinant PPI protein. (B) ESI-Q-TOF MS of purified recombinant PPI protein. The partial sequences of 4 peaks from the recombinant PPI were identified by MS/MS (Arrow).

purified $\sim 18 \mathrm{kDa}$ protein by the Ni-NTA system (Fig. 1A, lane 4). It was highly purified from crude extracts as a His-tagged protein. Recombinant PPI was identified via MALDI-TOF MS/MS. A total of four peaks from MALDI-TOF MS were analyzed by MS/MS and the following sequences were obtained (Fig. 1B, Arrow): i) VFFDMTIGGAPAGR; ii) VITDF MCQGGDFTR; iii) ADENFTLTHTGPGVLSMANAGK; and iv) NGSQFFLTTVK. This was $100 \%$ homologous to PPI (accession number KJ728870.1) using the MASCOT program and NCBI database.

Cell viability. Cell viability was determined with the CytoX assay, which relies on the mitochondrial metabolic capacity of viable cells. The results revealed that recombinant PPI exposure was not cytotoxic to HepG2 cells at any of the concentrations examined, between 0.001 and $1 \mu \mathrm{g}-\mathrm{ml}^{-1}$ (Fig. 2A). Treatment with $\mathrm{H}_{2} \mathrm{O}_{2}$ for $1 \mathrm{~h}$ decreased cell viability to $59.9 \%$ that of control cells; co-treatment with recombinant PPI did not alter the $\mathrm{H}_{2} \mathrm{O}_{2}$-induced decrease in cell viability, which remained constant at $60.4 \%$ (at $0.001 \mu \mathrm{g}-\mathrm{ml}^{-1}$ recombinant PPI), $54.7 \%$ (at $0.01 \mu \mathrm{g}-\mathrm{ml}^{-1}$ recombinant PPI), $55.5 \%$ (at $0.1 \mu \mathrm{g}-\mathrm{ml}^{-1}$ recombinant PPI) and $55.4 \%$ (at $1.0 \mu \mathrm{g}-\mathrm{ml}^{-1}$ recombinant PPI). These results demonstrate that recombinant PPI treatment did not prevent apoptosis from $\mathrm{H}_{2} \mathrm{O}_{2}$-induced oxidative stress However, the recombinant PPI was not toxic to HepG2 cells. Therefore, recombinant PPI was then tested further for its antioxidant.

Inhibition of ROS production. DCF-DA staining was used to examine whether recombinant PPI exposure inhibited ROS production in HepG2 cells co-treated with $\mathrm{H}_{2} \mathrm{O}_{2}$. HepG2 cells were challenged with $\mathrm{H}_{2} \mathrm{O}_{2}$, and the resulting ROS levels were $29.7 \%$ greater compared with the unchallenged control. Pretreatment of cells with the various concentrations of recombinant PPI $\left(0.001-1 \mu \mathrm{g}-\mathrm{ml}^{-1}\right)$ reduced the $\mathrm{H}_{2} \mathrm{O}_{2}$-mediated increase in ROS formation (Fig. 2B). Recombinant PPI treatment showed antioxidant effects in the presence of $\mathrm{H}_{2} \mathrm{O}_{2}$, implying that PPI directly scavenges ROS or other free radicals.

Induction of antioxidant enzyme activities in HepG2 cells. To investigate whether the antioxidant properties of recombinant
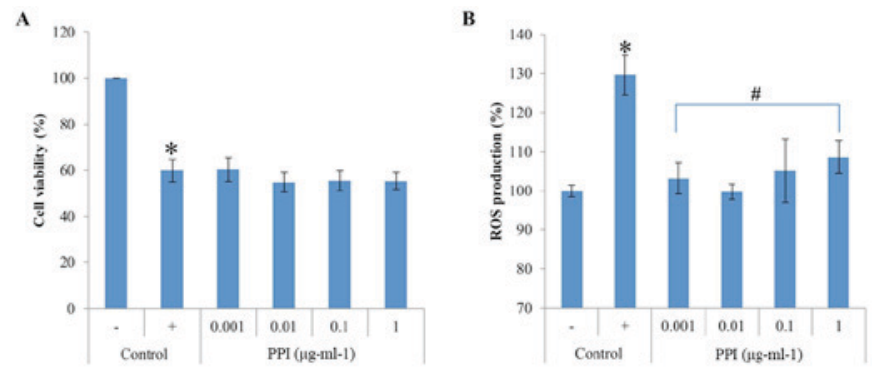

Figure 2. Effect of recombinant PPI in HepG2 cells (A) Recombinant PPI toxicity. (B) Effects of PPI on the formation of $\mathrm{H}_{2} \mathrm{O}_{2}$-induced ROS. Cells were pretreated with 2',7'-dichlorofluorescin diacetate for $20 \mathrm{~min}$ and exposed to PPI. Values are expressed as the mean \pm standard deviation $(n=3)$. ${ }^{*} \mathrm{P}<0.05$ vs. untreated control; ${ }^{\#} \mathrm{P}<0.05$ vs. $\mathrm{H}_{2} \mathrm{O}_{2}$ treated control. -, control cells without $\mathrm{H}_{2} \mathrm{O}_{2} ;+$, control cells treated with $1 \mathrm{mM} \mathrm{H}_{2} \mathrm{O}_{2} ; \mathrm{H}_{2} \mathrm{O}_{2}$, hydrogen peroxide; PPI, peptidylprolyl cis-trans isomerase; ROS, reactive oxygen species.

PPI are related to antioxidant enzyme induction, HepG2 cells were treated with recombinant PPI and the activity of the antioxidant enzymes CAT, GPx, SOD and TRR were measured. As shown in Fig. 3A, CAT activity was dramatically downregulated by $\mathrm{H}_{2} \mathrm{O}_{2}$ treatment, whereas the addition of recombinant PPI (0.001-1 $\mu \mathrm{g}-\mathrm{ml}^{-1}$ ) was able to restore CAT activity. GPx activity was reduced by $14 \%$ when cells were exposed to $\mathrm{H}_{2} \mathrm{O}_{2}$, but levels recovered in the presence of recombinant PPI at $1 \mu \mathrm{g}-\mathrm{ml}^{-1}$ (Fig. 3B). The activity of SOD was not altered by $\mathrm{H}_{2} \mathrm{O}_{2}$ however, increased with the treatment of recombinant PPI (Fig. 3C). PPI treatment at concentrations between 0.01 and $1 \mu \mathrm{g}-\mathrm{ml}^{-1}$ was able to increase the $\mathrm{H}_{2} \mathrm{O}_{2}$-induced decrease in TRR activity (Fig. 3D). Recombinant PPI treatments increased the activities of CAT, GPx and TRR that were reduced by exposure to $\mathrm{H}_{2} \mathrm{O}_{2}$. The results also indicated that recombinant PPI was also able to significantly increase SOD activity. Therefore, recombinant PPI appears to exert its antioxidant effects by modulating the activities of endogenous antioxidant enzymes.

Induction of antioxidant enzyme expression in HepG2 cells. In addition to its effects on antioxidant enzyme activities, the effects of recombinant PPI on mRNA expression were evaluated in HepG2 cells. In cells treated with $\mathrm{H}_{2} \mathrm{O}_{2}$, CAT mRNA 

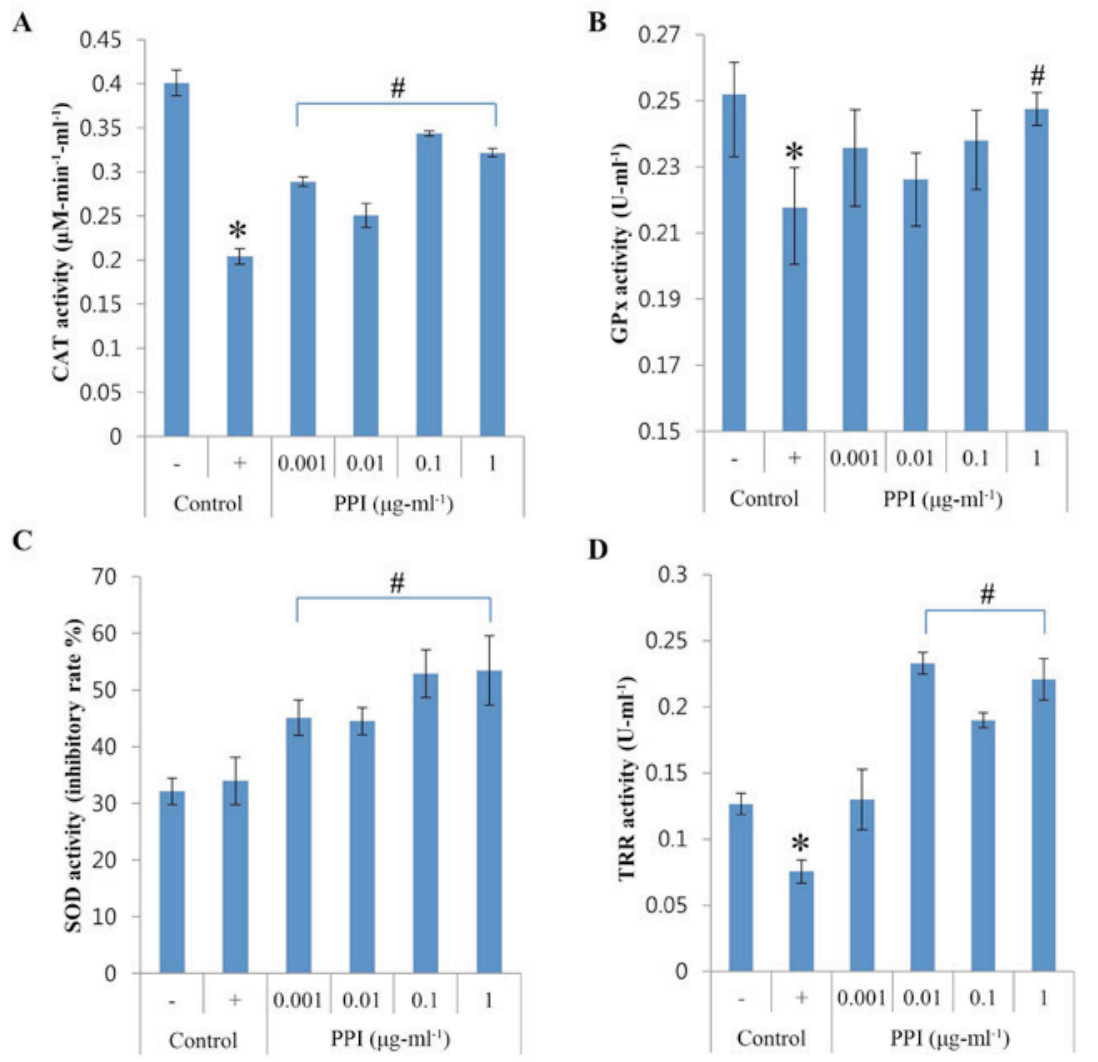

Figure 3. Effects of PPI on SOD, GPx, CAT and TRR activities in $\mathrm{H}_{2} \mathrm{O}_{2}$-treated $\mathrm{HepG} 2$ cells. (A) CAT activity; (B) GPx activity; (C) SOD activity; and (D) TRR activity. Values represent the mean \pm standard deviation $(\mathrm{n}=3)$. ${ }^{*} \mathrm{P}<0.05$ vs. untreated control; ${ }^{*} \mathrm{P}<0.05$ vs. $\mathrm{H}_{2} \mathrm{O}_{2}$-treated control. -, control cells without $\mathrm{H}_{2} \mathrm{O}_{2} ;+$, control cells treated with $1 \mathrm{mM} \mathrm{H}_{2} \mathrm{O}_{2}$; CAT, catalase; GPx, glutathione peroxidase; $\mathrm{H}_{2} \mathrm{O}_{2}$, hydrogen peroxide; PPI, peptidylprolyl cis-trans isomerase; ROS, reactive oxygen species; SOD, superoxide dismutase; TRR, thioredoxin reductase.
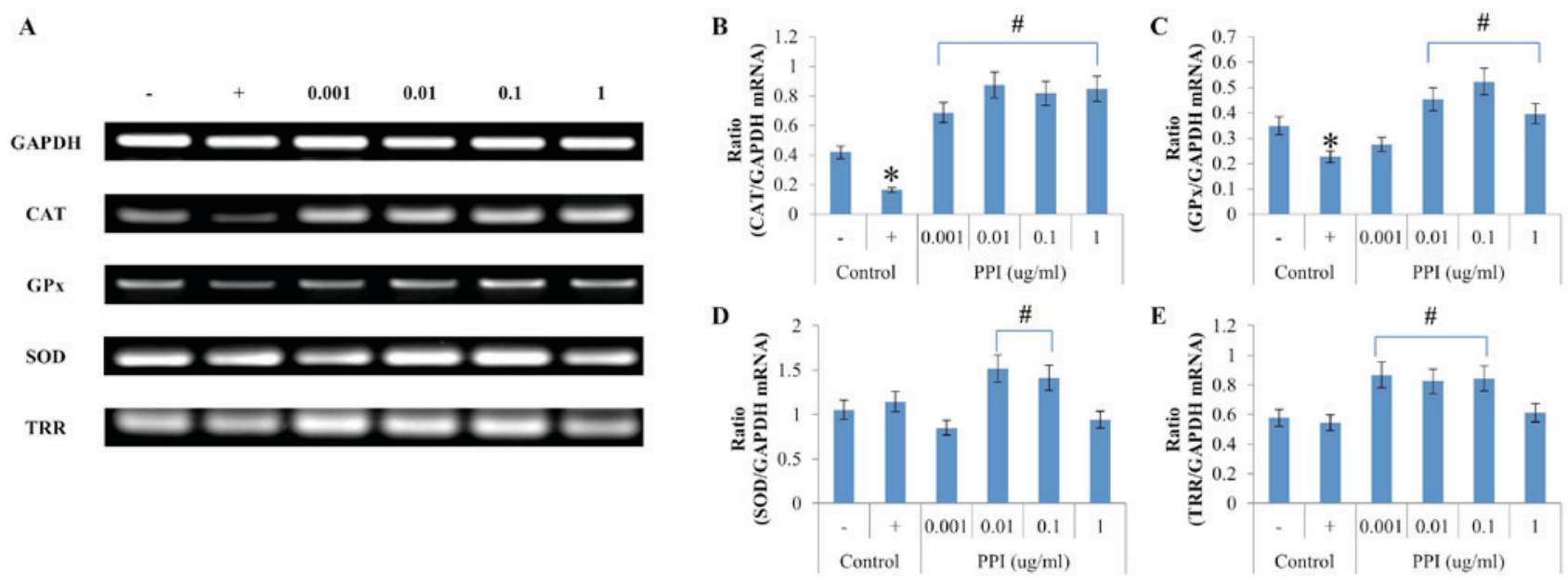

Figure 4. Effects of PPI on antioxidant enzymes mRNA expressions in $\mathrm{H}_{2} \mathrm{O}_{2}$ treated $\mathrm{HepG} 2$ cells. (A) Reverse transcription-polymerase chain reaction analysis of SOD, GPx, CAT and TRR. (B-E) Data quantification of antioxidant enzyme/GAPDH mRNA expression for (B) CAT, (C) GPx, (D) SOD, and (E) TRR. Values represent the mean \pm standard deviation $(\mathrm{n}=3)$. ${ }^{*} \mathrm{P}<0.05$ vs. untreated control; ${ }^{*} \mathrm{P}<0.05$ vs. $\mathrm{H}_{2} \mathrm{O}_{2}$-treated control. - , control cells without $\mathrm{H}_{2} \mathrm{O}_{2}$; +, control cells treated with $1 \mathrm{mM} \mathrm{H}_{2} \mathrm{O}_{2}$; CAT, catalase; GPx, glutathione peroxidase; $\mathrm{H}_{2} \mathrm{O}_{2}$, hydrogen peroxide; PPI, peptidylprolyl cis-trans isomerase; ROS, reactive oxygen species; SOD, superoxide dismutase; TRR, thioredoxin reductase.

expression levels of were significantly diminished compared with the $\mathrm{H}_{2} \mathrm{O}_{2}$-treated -treated controls and GAPDH mRNA expression (Fig. 4A and B). $\mathrm{H}_{2} \mathrm{O}_{2}$ exposure significantly decreased CAT mRNA expression level, which was then reversed five-fold by addition of $0.01 \mu \mathrm{g}-\mathrm{ml}^{-1}$ recombinant PPI.
The level of GPx mRNA expression was highest (ratio 0.52) when cells were pretreated with recombinant PPI at a concentration of $0.1 \mu \mathrm{g}-\mathrm{ml}^{-1}$ (Fig. 4A,C). The results demonstrated that treatment with $\mathrm{H}_{2} \mathrm{O}_{2}$ led to decreased CAT and GPx mRNA expression; however, SOD and TRR mRNA expression levels 
were not affected by $\mathrm{H}_{2} \mathrm{O}_{2}$ treatment (Fig. 4A,D and E). SOD mRNA expression was significantly increased when treated with 0.01 and $0.1 \mu \mathrm{g}-\mathrm{ml}^{-1}$ recombinant PPI, as compared with the positive control (Fig 4A and D). TRR mRNA levels were highest (ratio 0.87) at a concentration of $0.001 \mu \mathrm{g}-\mathrm{ml}^{-1}$ recombinant PPI (Fig. 4A and E). Recombinant PPI treatment in HepG2 cells increased the level of mRNA expression of reduced antioxidant enzymes when cells were treated with $\mathrm{H}_{2} \mathrm{O}_{2}$. Therefore, PPI increased the expression of the majority of antioxidant enzymes, however this differed depending on the concentration of PPI.

\section{Discussion}

The findings of the present study supported the hypothesis that recombinant PPI has multiple antioxidant properties that enable it to protect cells. First, recombinant PPI treatment made cells more resistant to $\mathrm{H}_{2} \mathrm{O}_{2}$-induced oxidative stresses. Second, recombinant PPI treatment increased antioxidant enzyme activities, providing cells with a higher capacity for scavenging ROS. Accordingly, recombinant PPI increased the $\mathrm{H}_{2} \mathrm{O}_{2}$-induced decreases in antioxidant enzyme activity and their mRNA expression. These data suggest that recombinant PPI cloned from the red algae $P$. yezoensis may be able protect cells as an inducer of antioxidant enzymes. PPI treatment increased the activities of antioxidant enzymes, such as CAT, GPx, SOD and TRR.

The mechanism of cell repair against oxidative stress is directly or indirectly regulated by antioxidants. Direct-regulation of antioxidants is possible at low concentrations, however the period of activation time is short. Conversely, the indirect-regulation of antioxidants may occur via the Kelch ECH associating protein 1/nuclear factor erythroid 2-related factor 2/antioxidant response element (Keap1/Nrf2/ARE) pathway, which is relatively long-lasting (35). When oxidative stress was induced by $1 \mathrm{mM} \mathrm{H}_{2} \mathrm{O}_{2}$, the activities of CAT and GPx, which primarily act to remove $\mathrm{H}_{2} \mathrm{O}_{2}$, were decreased. In addition, the activity of TRR, which helps PRDX directly remove $\mathrm{H}_{2} \mathrm{O}_{2}$, decreased. This suggested that the antioxidant enzymes in the cell disappeared following activation to remove the increased $\mathrm{H}_{2} \mathrm{O}_{2}$. However, the activity of SOD which is not directly involved in the removal of $\mathrm{H}_{2} \mathrm{O}_{2}$ was not different compared with the negative control.

The treatment of $0.001 \mu \mathrm{g}-\mathrm{ml}^{-1}$ recombinant PPI directly increased the activities of CAT, GPx and TRR to remove $\mathrm{H}_{2} \mathrm{O}_{2}$, thereby reducing the intracellular ROS. In addition, as a result of primary antioxidant activity, SOD activity was increased to remove newly generated ROS. The recombinant PPI treatment of $0.001 \mu \mathrm{g}-\mathrm{ml}^{-1}$ increased the mRNA expressions of CAT, GPx and TRR and did not increase the mRNA expression of SOD. This suggests that the recombinant PPI concentration of $0.001 \mu \mathrm{g}-\mathrm{ml}^{-1}$ does not affect the expression of SOD, and that the increase in SOD activity may be self-regulated in cells to remove newly generated ROS. In addition, an increase in TRR mRNA expression aided PRDX, which is directly associated with $\mathrm{H}_{2} \mathrm{O}_{2}$.

When treated with $1 \mu \mathrm{g}-\mathrm{ml}^{-1}$ recombinant PPI, the SOD activity was $53.4 \%$, which was increased compared with the positive control. However, expression of mRNA was decreased compared with the positive control. These results suggested that the SOD antioxidant activity was not regulated by its associated signaling pathway, however by the antioxidant activity of the recombinant PPI. It has been reported that the recombinant PPI of the sweet potato roots gene has its own antioxidant activity (36). The recombinant PPI in the present study exhibited $20 \%$ antioxidant activity in vitro at $1 \mu \mathrm{g}-\mathrm{ml}^{-1}$ (data not shown). Therefore, the results of SOD activity and mRNA expression are different due to the fact that the antioxidant activity of SOD is regulated by that of PPI.

The recombinant PPI treatment of 0.01-0.1 $\mu \mathrm{g}-\mathrm{ml}^{-1}$ increased the activities of CAT, GPx, SOD and TRR, and mRNA expression was high. It is predicted that recombinant PPI regulates the Keap1/Nrf2/ARE signal pathway for antioxidant enzyme expression. Therefore, the regulation of antioxidation by recombinant PPI directly promoted the activity of antioxidant enzymes, however was also indirectly controlled. Recently, Lee et al (37) reported that Cyp including PPI, binds to TRR and enhances its antioxidant activity. When the recombinant PPI is treated at a concentration of 0.01 or more, the activity of TRR may be rapidly increased due to the combination of PPI and TRR.

However, the expression of mRNA does not entirely determine the activity of the enzyme (38). Therefore, the present study primarily confirmed the activity and mRNA expression alterations of antioxidant enzymes that regulate induced oxidative stress. Gene regulation and enzyme activity combinations were additionally predicted. In the majority of cases, the expression of mRNA was directly associated with the regulation of the antioxidant enzyme activity. However, when treated with $0.001 \mu \mathrm{g} / \mathrm{ml}$ of PPI, the expression of TRR mRNA rapidly increased, whereas the activity of TRR was decreased compared with other experimental groups. Further experimentation is therefore required on TRR, PRDX and their associated regulatory mechanisms.

The present study revealed for the first time, to the best of our knowledge, the antioxidant properties of $P$. yezoensis recombinant PPI. The results of the present study indicated that recombinant PPI treatment controlled the expression of antioxidant enzymes and maintained the antioxidant capacity of the cell. Additional studies into the interaction between recombinant PPI and antioxidant enzymes are necessary to elucidate the antioxidant mechanisms including the Keap1/Nrf2/ARE signal pathway of recombinant PPI in the cell.

The present study also reported for the first time, and to the best of our knowledge, the isolation of PPI mRNA from $P$. yezoensis. The biochemical and physiological effects of recombinant PPI protein during oxidative stress requires further study. However, results from the present study suggest that recombinant PPI is an excellent candidate for the development of therapeutically useful antioxidant agents.

\section{Acknowledgements}

The present study was supported by The Basic Science Research Program through the National Research Foundation of Korea, funded by the Ministry of Education (grant no. 2012R1A6A1028677).

\section{References}

1. Harman D: Role of free radicals in aging and disease. Ann N Y Acad Sci 673: 126-141, 1992. 
2. Bhattacharyya A, Chattopadhyay R, Mitra S and Crowe SE: Oxidative stress: An essential factor in the pathogenesis of gastrointestinal mucosal diseases. Physiol Rev 94: 329-354. 2014.

3. Bentley AR, Emrani P and Cassano PA: Genetic variation and gene expression in antioxidant related enzymes and risk of COPD: A systematic review. Thorax 63: 956-961, 2008.

4. Lobo V, Patil A, Phatak A and Chandra N: Free radicals, antioxidants and functional foods: Impact on human health. Pharmacogn Rev 4: 118-126, 2010.

5. Young IS and Woodside JV: Antioxidants in health and disease. J Clin Pathol 54: 176-186, 2001.

6. Apel K and Hirt H: Reactive oxygen species: Metabolism, oxidative stress, and signal transduction. Annu Rev Plant Biol 55: 373-399, 2004

7. Zelko IN, Mariani TJ and Folz RJ: Superoxide dismutase multigene family: A comparison of the CuZn-SOD (SOD1), Mn-SOD (SOD2), and EC-SOD (SOD3) gene structures, evolution, and expression. Free Radic Biol Med 33: 337-349, 2002.

8. Flora SJ: Structural, chemical and biological aspects of antioxidants for strategies against metal and metalloid exposure. Oxid Med Cell Longev 2: 191-206, 2009.

9. de M Bandeira S, da Fonseca LJ, da S Guedes G, Rabelo LA, Goulart MO and Vasconcelos SM: Oxidative stress as an underlying contributor in the development of chronic complications in diabetes mellitus. Int J Mol Sci 14: 3265-3284, 2013

10. Takahashi N, Hayano T and Suzuki M: Peptidyl-prolyl cis-trans isomerase is the cyclosporin A-binding protein cyclophilin. Nature 337: 473-475, 1989.

11. Pérez de Lema G, Arribas-Gómez I, Ruiz-Ginés JA, de Arriba G, Prieto A, Rodriguez-Puyol D and Rodriguez-Puyol M: Reactive oxygen species mediate the effects of cyclosporine A on human cultured mesangial cells. Transplant Proc 29: 1241-1243, 1997.

12. McGrath LT, Treacy R, McClean E and Brown JH: Oxidative stress in cyclosporin and azathioprine treated renal transplant patients. Clin Chim Acta 264: 1-12, 1997.

13. Zhong Z, Arteel GE, Connor HD, Yin M, Frankenberg MV, Stachlewitz RF, Raleigh JA, Mason RP and Thurman RG: Cyclosporin A increases hypoxia and free radical production in rat kidneys: Prevention by dietary glycine. Am J Physiol 275: F595-F604, 1998.

14. Brazin KN, Mallis RJ, Fulton DB and Andreotti AH: Regulation of the tyrosine kinase Itk by the peptidyl-prolyl isomerase cyclophilin A. Proc Natl Acad Sci USA 99: 1899-1904, 2002.

15. Ferreira PA, Nakayama TA, Pak WL and Travis GH Cyclophilin-related protein RanBP2 acts as chaperone for red/green opsin. Nature 383: 637-640, 1996.

16. Galat A: Variations of sequences and amino acid compositions of proteins that sustain their biological functions: An analysis of the cyclophilin family of proteins. Arch Biochem Biophys 371: 149-162, 1999

17. Horowitz DS, Lee EJ, Mabon SA and Misteli T: A cyclophilin functions in pre-mRNA splicing. EMBO J 21: 470-480, 2002.

18. Krzywicka A, Beisson J, Keller AM, Cohen J, Jerka-Dziadosz M and Klotz C: KIN241: A gene involved in cell morphogenesis in Paramecium tetraurelia reveals a novel protein family of cyclophilin-RNA interacting proteins (CRIPs) conserved from fission yeast to man. Mol Microbiol 42: 257-267, 2001.

19. Leverson JD and Ness SA: Point mutations in v-Myb disrupt a cyclophilin-catalyzed negative regulatory mechanism. Mol Cell 1: 203-211, 1998

20. Lin DT and Lechleiter JD: Mitochondrial targeted cyclophilin $\mathrm{D}$ protects cells from cell death by peptidyl prolyl isomerization. J Biol Chem 277: 31134-31141, 2002.
21. O'Connell S, Tuite N, Slattery C, Ryan MP and McMorrow T: Cyclosporine A-induced oxidative stress in human renal mesangial cells: A role for ERK 1/2 MAPK signaling. Toxicol Sci 126 101-113, 2012.

22. de Oliveira e Silva AM, Vidal-Novoa A, Batista-González AE, Pinto JR, Portari Mancini DA, Reina-Urquijo W and Mancini-Filho J: In vivo and in vitro antioxidant activity and hepatoprotective properties of polyphenols from Halimeda opuntia (Linnaeus) Lamouroux. Redox Rep 17: 47-53, 2012.

23. Ismail A Jr and Tan S: Antioxidant activity of selected commercial seaweeds. Malays J Nutr 8: 167-177, 2002.

24. Chandini SK, Ganesan P and Bhaskar N: In vitro antioxidant activities of three selected brown seaweeds of India. Food Chem 107: 707-713, 2008.

25. Kumar SR, Hosokawa M and Miyashita K: Fucoxanthin: A marine carotenoid exerting anti-cancer effects by affecting multiple mechanisms. Mar Drugs 11: 5130-5147, 2013.

26. Sathya R, Kanaga N, Sankar P and Jeeva S: Antioxidant properties of phlorotannins from brown seaweed Cystoseira trinodis (Forsskål) C. Agardh. Arab J Chem, 2013.

27. Yuan YV, Bone DE and Carrington MF: Antioxidant activity of dulse (Palmaria palmata) extract evaluated in vitro. Food Chem 91: 485-494, 2005.

28. Balboa EM, Conde E, Moure A, Falqué E and Domínguez H: In vitro antioxidant properties of crude extracts and compounds from brown algae. Food Chem 138: 1764-1785, 2013.

29. Ganesan P, Kumar CS and Bhaskar N: Antioxidant properties of methanol extract and its solvent fractions obtained from selected Indian red seaweeds. Bioresour Technol 99: 2717-2723, 2008

30. Hwang ES and Thi ND: Effects of extraction and processing methods on antioxidant compound contents and radical scavenging activities of laver (Porphyra tenera). Prev Nutr Food Sci 19: 40-48, 2014.

31. Fathi-Roudsari M, Akhavian-Tehrani A and Maghsoudi N: Comparison of three Escherichia coli strains in recombinant production of reteplase. Avicenna J Med Biotechnol 8: 16-22, 2016.

32. Abu-Reidah IM, Arráez-Román D, Quirantes-Piné R, FernándezArroyo S, Segura-Carretero A and Fernández-Gutiérrez A: HPLC-ESI-Q-TOF-MS for a comprehensive characterization of bioactive phenolic compounds in cucumber whole fruit extract. Food Res Int 46: 108-117, 2012.

33. Schmidt AJ, Heiser P, Hemmeter UM, Krieg JC and Vedder H: Effect of antidepressants on mRNA levels of antioxidant enzymes in human monocytic U-937 cells. Prog Neuro-Psychoph 32: 1567-1573, 2008

34. Aguilar-Melero P, Prieto-Álamo MJ, Jurado J, Holmgren A and Pueyo C: Proteomics in HepG2 hepatocarcinoma cells with stably silenced expression of PRDX1. J Proteomics 79: 161-171, 2013.

35. Dinkova-Kostova AT and Talalay P: Direct and indirect antioxidant properties of inducers of cytoprotective proteins. Mol Nutr Food Res 52 (Suppl 1): S128-S138, 2008.

36. Liao JC, Chiu CS, Chen HJ, Huang SS, Hou WC, Lin WC, Lin YH and Huang GJ: Characterization of a novel Cyclophilin-type peptidylprolyl isomerase protein from sweet potato storage roots. Botanical Studies 53: 315-324, 2012.

37. Lee SP, Hwang YS, Kim YJ, Kwon KS, Kim HJ, Kim K and Chae HZ: Cyclophilin A binds to peroxiredoxins and activates its peroxidase activity. J Biol Chem 276: 29826-29832, 2001.

38. Glanemann C, Loos A, Gorret N, Willis LB, O'Brien XM, Lessard PA and Sinskey AJ: Disparity between changes in mRNA abundance and enzyme activity in Corynebacterium glutamicum: Implications for DNA microarray analysis. Appl Microbiol Biotechnol 61: 61-68, 2003. 